\title{
Paul's ecstatic trance experience near Damascus in Acts of the Apostles
}

\author{
John J Pilch ${ }^{1}$ \\ Georgetown University, Washington, DC \\ Research Associate: Department of New Testament Studies \\ University of Pretoria
}

\begin{abstract}
Luke reports more than twenty altered states of consciousness experiences in Acts of the Apostles. These are common and normal human experiences in approximately ninety percent of contemporary cultures. In the ancient CircumMediterranean world, it seems to have been common and normal in about eighty percent of those cultures. Insights from psychological anthropology, cultural anthropology and cognitive neuroscience contribute to an improved understanding and interpretation of these experiences in the Bible, particularly the call of Paul as reported in Acts 9; 22; 26.
\end{abstract}

\section{INTRODUCTION}

Feeling hungry and waiting for a meal to be prepared, Peter goes at noon to the rooftop of the house to pray and falls into a trance. He sees the sky open and from it something like a great sheet containing all kinds of animals, reptiles and birds descends. Peter hears the command: "Rise, kill, and eat" (Ac 10:9). The day before this occurrence, Cornelius, a centurion of the Italian cohort, saw in mid-afternoon an angel of God who directed him to seek out Peter, lodging with Simon a tanner, in a house by the seaside (Ac 10:1-8). As he

\footnotetext{
1 Paper presented at the International Context Group Meeting at the University of Pretoria, June 2001. Prof Dr John J Pilch visited South Africa as Research Associate of Prof Dr Jan G van der Watt, Department of New Testament Studies, Faculty of Theology, University of Pretoria. Dr Pilch teaches Biblical Literature at Georgetown University, Washington. Recent publications include Social Scientific Models for Interpreting the Bible: Essays by the Context Group in Honor of Bruce J Malina, edited by J J Pilch (Leiden: E J Brill, 2001) and The Cultural World of the Apostles, The Second Reading, Sunday by Sunday: Year A (Collegeville: The Liturgical Press, 2001).
} 
is dying, Stephen gazes into the sky and sees the glory of God and Jesus standing at God's right hand (Ac 7:55-56). In almost every chapter of Acts of the Apostles, one or another person enters into trance or another altered state of consciousness, communicates with a being in alternate reality, and learns new information or receives a new direction in life. Luke reports more than twenty such experiences in Acts, and others in his gospel too: the baptism and testing Jesus, the transfiguration of Jesus (Pilch 1994), and experiences of the Risen Jesus by his followers (Pilch 1998a; 2001). In fact, altered states of consciousness experiences fill the Bible beginning with Genesis when God puts the first creature into a deep sleep in order to create Eve, his helpmate (Gn 2:21) and ending with Revelation where John the Revealer repeats four times that what he reports is the result of experiences in trance (en pneumati: Rv 1:10; 4:2; 17:3; 21:10; Malina and Pilch 2000; Pilch 1993). According to the Deuteronomic Historian, trance experiences were one means that God used for communicating with human beings: "The word of the LORD was rare in those days; there was no frequent vision" (1 Sm 3:1-21).

In order to gain some appreciation of the ecstatic trance experiences reported in Acts of the Apostles, we review some insights from cultural anthropology and cognitive neuroscience and then we examine the experience of Paul often called his "conversion."

\section{TERMINOLOGY}

To facilitate reflection on this topic and to contribute to fruitful discussion, we begin with a definition of some terms. For our purposes, consciousness can be defined as: "the totality ... of sensations, perceptions, ideas, attitudes, and feelings of which an individual or a group is aware at any given time or within a given time span" (Pease 1993:140). Consciousness therefore is basically awareness, being aware of many things.

The traditional phrase "altered states of consciousness" raises a number of issues (Pilch 1996). Scholars continue to use it because the phrase is commonly accepted, but they recognize that it must be qualified. The word "state" is misleading since it implies a continuity of consciousness. As Milton Erickson has noted: "The apparent continuity of consciousness that exists in everyday normal awareness is in fact a precarious illusion that is only made possible by the associative connections that exist between related bits of conversation, task orientation, etc." (Quoted from Rossi 1986:111 who quotes Erickson; 
see also Rakowska 2000:41-50). These associative connections are rooted in the nature of the brain and its operation (d'Aquili \& Newberg 1999; Goldman 1999). We shall return to this topic below, but in brief the brain stores the information it gathers somewhat after the fashion of a computer which marks information with a "date and time" indicator so that it can be retrieved from the various parts of the hard-drive on which it is stored.

Following Ludwig, Erika Bourguignon defines altered states of consciousness (ASCs) as "conditions in which sensations, perceptions, cognition and emotions are altered. They are characterized by changes in sensing, perceiving thinking, and feeling. They modify the relation of the individual to the self, body, sense of identity, and the environment of time, space, or other people" (Bourguignon 1979:236). Krippner (1972) has identified twenty states of consciousness, and we shall return to this topic below.

Finally, in trance or in any other altered state of consciousness a visionary encounters, indeed enters, another level or aspect of reality. Goodman distinguishes between ordinary secular reality (I prefer the phrase, culturally "normal" or consensual reality) and alternate (or non-consensual, or non ordinary) reality, a twin of the ordinary secular one (Gore 1995:x). Both comprise the totality of reality. Culturally "normal" or consensual reality is that aspect or dimension of reality of which a person is most commonly aware most of the time. Alternate reality describes that dimension of reality in which the deity and spirits reside, which human beings from culturally "normal" reality can sometimes visit in ecstatic trance by taking a journey (variously called "sky journey" or "soul loss" and the like), and to which people go when they die. (Those who do not believe any of these things would call this non-consensual reality.)

\section{ECSTATIC TRANCE AND CULTURAL ANTHROPOLOGY}

The work of psychological anthropologists Erika Bourguignon (1976; 1979; see also Pilch 1993) and Felicitas Goodman (1990, 1972; Goodman, Henny \& Pressel 1974) is foundational. Bourguignon reviewed the ethnographic data in the Human Relations Area Files (HRAF) at Yale University and found that altered states of consciousness (ASCs) existed in ninety percent of the 488 societies she studied. Among these were Ancient Egypt, Greeks, Hebrews and forty-one other Circum-Mediterranean societies. In this 
region of the world, ASCs exist in eighty percent of the societies. Bourguignon observed that "societies which do not utilize these states clearly are historical exceptions which need to be explained, rather than the vast majority of societies that do use these states" (1976:51). Clottes and Lewis-Williams confirm that statement with their claim that at all times and in all places people have entered a variety of altered states of consciousness. "Indeed the potential to shift, voluntarily or involuntarily, between different states of consciousness is a function of the universal human nervous system. All people have to cope with different states of consciousness in one way or another" (Clottes and LewisWilliams1996:12).

Why, then, do some societies appear to lack ASC experiences? Physiciananthropologist Arthur Kleinman offers an explanation (see Pilch 1993:233). "Only the modern, secular West seems to have blocked an individual's access to these otherwise pan-human dimensions of the self." When science in the seventeenth century disrupted the bio-psycho-spiritual unity of human consciousness that had existed until then, Westerners developed an "acquired consciousness" whereby they can dissociate the self and look at the self "objectively." This metaself does not allow the total absorption in lived experience which is the very essence of highly focused ASCs. The basis for the pan-human potential lies in the human nervous system which we shall consider below (see also Winkelman 1997).

As already mentioned, Stan Krippner (1972:1-5) has enumerated twenty states of consciousness: dreaming, sleeping, hypnagogic (drowsiness before sleep), hypnopompic (semi-consciousness preceding waking), hyperalert, lethargic, rapture, hysteric, fragmentation, regressive, meditative, trance, reverie, daydreaming, internal scanning, stupor, coma, stored memory, expanded consciousness, and "normal." These states of consciousness actually shade one into another along a continuum with "alert" at one end and deep states (trance) at the other. Thus alert consciousness sometimes gives way to daydreaming in which one is less alert. Next there is dreaming and lucid dreaming - a state between waking and sleeping in which people can control or learn to control their imagery. In fact, controlling the imagery of one's altered state of consciousness is a key part of a shaman's technique (Clottes and Lewis-Williams 1996:14), but all visionaries control the imagery of their trance. In deep states of trance, all the senses are involved: 
people see, hear, smell, feel, and taste things. They experience a variety of sensations in their bodies. Indeed, for some people, the trance experience is principally kinesthetic.

From her research on glossolalia, Goodman concluded that this experience took place in a specialized state of consciousness known as the religious trance state (for an application to Ac, see Esler 1992). She also calls it the ecstatic trance state, for it can be achieved by ritualized behavior and rhythmic stimulation of the nervous system. We adopt this phrase and broaden it in this paper to describe Paul's so-called "conversion experience."

\section{ECSTATIC TRANCE AND COGNITIVE NEUROSCIENCE}

All human beings are $100 \%$ the same (by nature; biology), at the same time that they are $100 \%$ different (as individuals), and 50\% the same and 50\% different (by culture; see Malina 2001:8). It is our common biology that explains why ASCs are, as Kleinman has stated, a pan-human potential for those who do not block it. Recent research on the human brain and nervous system not only explains how ecstatic trance experiences occur and why they are a universal human experience but also helps human beings to interpret these experiences. In particular, this knowledge will help all readers of the Bible, professional and ordinary lay people, to understand and interpret reports of ecstatic trance experiences. We rely on the publications and research consulted by the late E G d'Aquili and A B Newberg (1993, but especially 1999 which incorporates and refines their previous publications).

In general, ecstatic trance can be induced neurologically in one of two ways: "from the bottom up," or "from the top down" (d'Aquili \& Newberg 1999:23-27, 99102). Inducing a trance "from the bottom up" involves the brain and the autonomic nervous system which has two components: the sympathetic or arousal subsystem and the

parasympathetic or quiescent subsystem. The autonomic nervous system connects the brain with the rest of the body and plays a key role in generating basic emotions like fear, joy, and shame. The sympathetic or arousal subsystem helps human beings adapt to beneficial and harmful stimuli in the environment principally through the "fight or flight" response. This subsystem can halt digestion, increase the heart rate and blood pressure, increase respiration, decrease salivation, and the like. The parasympathetic or quiescent 
subsystem maintains homeostasis and conserves the body's resources and energy. This subsystem controls such things as cell growth, digestion, relaxation, sleep. In other words, it deals with vegetative functions and maintenance activities. By stimulating (handclapping, drumming, rattling, and the like) or quieting (as happens in normal sleep, chanting, reciting a mantra, and the like) the senses, it is possible to produce a brief but intense ecstatic trance experience.

Inducing a trance "from the top down" involves activities that begin in the cortex of the brain and then move down into the autonomic nervous system. Meditation or any other form of intense concentration is a common strategy for inducing this kind of trance. It is manifest in an extraordinary state of relaxation. The meditation can be positive, that is, the meditator can focus on one idea to the exclusion of all others, or it can be negative, that is, the meditator can deliberately attempt to remove all ideas from consciousness. The result would be a hyperquiescent state, an ecstatic trance experience of longer duration. If on his mission to arrest members of the Jesus movement, Paul was intensely focused on the fraud and deceptive teacher he considered Jesus to be, it is plausible that such intense focus on one idea contributed to inducing the altered state of consciousness in which he encountered the risen Jesus on the road to Damascus.

Other neuropsychological scientists have identified and described three overlapping stages of ecstatic trance (Siegel 1977; for application to shamanic trance, see Dowson 1992:29-65; Clottes \& Lewis-Williams 1996:16-19). They note that it is not important for a visionary to pass through all three stages, but the three stages seem to cover the range of possible experience. In the first, or lightest stage of trance, visionaries see various geometric forms: dots, zigzags resembling lightning strikes, lines or sticks that may be parallel, crossed, vertical, horizontal, and the like. One also sees bright colors that can flicker, pulsate, or blend with one another. To see pale white, therefore, is a fairly good indicator one is in trance. To see only black or dark could mean one has not yet entered trance or that one has left it. The colors relate to different levels neurological activity and different brain wave activity. Some societies give meanings to these geometric forms, while others do not. For example, the South American Tukano interpret brilliant dots as the Milky Way, the goal of sky journeys (Reichel-Dolmatoff 1978). To 
see them would indicate to the visionary that she or he has arrived at the journey's goal. However, many meanings are possible and do exist.

In the second stage, the visionary attempts to make sense of the geometric forms by imagining or illusioning them into significant objects. Visionaries who adopt the hunter-gatherer modalities tend to see animals. The animals have various meanings. Some are animal-guides, others give healing, strength, or other gifts. Other visionaries select objects of personal, religious, emotional, or still other significance. Thus, the bright light or white color seen by some visionaries in Ac would plausibly be associated with the realm of God. Yahweh's glory is always described as bright light (see below p. 11). Sometimes the visionary's emotional state influences the interpretation. If a person is thirsty, the object might become a cup of water; if the person is frightened, the object could become a knife, gun, or bomb. Peter's emotional state (hunger) occasioned the content of his vision reported in Acts 10 and later its interpretation

The third stage, deep trance, is ordinarily reached through a tunnel, a vortex, a narrow passage-way of some sort between culturally "normal" reality and alternate reality. Sometimes visionaries see a lattice along the sides of the passage-way. This appears to be what becomes of the geometric imagery from stage one. Visionaries may begin to see animals, people, or other objects in the lattices. At the end of the passageway the visionary arrives in a bright place (or sometimes a place of subdued light). Sometimes this world seems bizarre, and in this stage visionaries can journey, fly like birds, or even change (metamorphose) into birds or animals. This impression, however, is a first impression. When the trance experience is ended, the visionary gives unusual experiences an interpretation that makes good sense. This is often facilitated by longer reflection, further analysis, or discussion with others especially if the trance was experienced in a group or communal setting.

Clottes and Lewis-Williams (1996:19) underscore the fact that these three stages are universal and hard-wired, as it were, into the human nervous system. They assume that the nervous system of Upper Paleolithic beings was essentially the same nervous system human beings have today. "It seems likely," they write, "that Australopithecine (E \& S Africa; 1.4 million years ago) hallucinated [this is the word they use to describe ASCs or trance experiences], highly probable that Neanderthals $(100,000-35,000$ years 
ago) hallucinated, and certain that at least some of the anatomically modern human beings of the Upper Paleolithic [35,000-8,000 years ago] also hallucinated" (Clottes \& Lewis-Williams 1996:81). These researchers are using the word "hallucinate" in a nonjudgmental sense. Unfortunately, that word in modern psychiatry as well as in common parlance is generally associated with a disorder of the nervous system. No anthropologist shares this belief. It would be preferable in this discussion, therefore, to replace that word with something like "see visions."

This universal propensity for the human nervous system to enter altered states is therefore very ancient, and it forced human beings to make sense of such experiences. People who experienced and entered these states took on special status and ritualized the experiences to help make better sense of their way of life. Anthropologists call such people shamans and describe shamans as ritual specialists. In the biblical context, such people are known as "holy men/women" (hasid; saddiq; see Pilch 1998) A final but important observation is that the meanings given by the visionary to the experiences in each of these stages is culture specific. To quote Clottes and Lewis-Williams (1996:19) with adaptation "At least in some measure, people see in visions [hallucinate] what they expect to see [hallucinate]."

\section{PAUL'S ECSTATIC TRANCE REPORTED IN ACTS OF THE APOSTLES}

Acts of the Apostles reports more than twenty group and individual ecstatic trance encounters with beings in alternate reality, such as God, the Risen Jesus, the Spirit, angels, and other spirits. Let us focus on the so-called conversion of Paul reported in three places: Acts 9:1-19; 22:3-21 and 26:9-18. Instead of calling this event the conversion of Paul, which is an interpretation of the event reported, or more correctly one of its results, it is more appropriate to name this event as the call of Paul by God to a special function. From the viewpoint of cultural anthropology and cognitive neuroscience, this is a report of Paul's encounter in an altered state of consciousness with the Risen Jesus in alternate reality. Insights about ecstatic trance from these scientific, academic disciplines help to explain what the basic event might plausibly have been and why Luke was able to interpret it as he did. In this article, we rely upon Gerhard 
Lohfink's (1966) literary analysis as our basic guide to understanding these three textsegments.

To begin with, in the epistles Paul never reports his "call" in such detail as in these reports by Luke. Paul deliberately links his experience to the Easter experiences of the other Apostles who personally knew Jesus in his life time: "last of all, as to one untimely born, he appeared to me" (or was seen by me; 1 Cor 15:3-9). Scholars agree that while Luke is careful to distinguish Paul from the other Apostles by designating him as a great envoy to non-believers (Ac 1:21-22), Paul repeatedly insists that he is indeed an apostle (e g Gl 1:1). This, however, is not a concern in our study. We are concerned rather with the pivotal experience in Paul's life which both Paul and Luke acknowledge, and which Luke presents differently and in more detail than does Paul.

Paul's experience of the Risen Jesus takes place in an ecstatic trance. Modern travelers are familiar with road trance. Hypnotized by the highway or the boredom of the trip, a modern traveler often arrives safely at a destination to which she or he was driving without explicitly remembering the route, the traffic lights or the turns. Research indicates that human beings shift often between states of consciousness during a day, even in the company of others. Students attending a class lecture or scholars participating in a seminar or conference can attest to this experience, no matter how small and intimate the group. That Paul is traveling (whether walking or riding) with companions would therefore not rule out the plausibility of his falling into ecstatic trance.

The bright light from heaven (Ac 9:3; 22:6) even brighter than the sun (26:13) that Paul saw is typical of stage one of an ecstatic trance. That he does not report seeing geometric forms is not significant. Either Paul did not experience them, or never referred to this element, or the tradition or Luke omitted it. In the Israelite tradition, light is the manifestation of God's honor or glory (Is 60:1; 62:1; Lk 2:9), that is, God's very self. The light takes the form of a cloud (Ex 24:15ff) or fire (Dt 5:24) flashing brightly (Ez $1: 4,27-28 ; 10: 4)$. From a neurological perspective, the bright color signals a shift in consciousness. From an ideological (theological, personal meaning) perspective, Paul the Pharisee familiar with light in the Israelite tradition would be aware that he had entered alternate reality or that some being from alternate reality might be initiating communication with him. 
Next Paul hears a voice asking him a question: "Saul, Saul, why do you persecute me?" (Ac 9:4; 22:7; 26:14). Ecstatic trance experiences often reflect and include recent personal experiences (Goldman 1999). The author of Acts introduced Paul by noting that he kept safe the cloaks of those who were stoning Steven while he also witnessed the death of this follower of Jesus (Ac 7:58). This event stirred a great persecution in which Paul became a major force: "ravaging the church, and entering house after house, he dragged off men and women and committed them to prison" (Ac 8:1-3). On the road to Damascus, Paul was "still breathing threats and murder against the disciples of the Lord" (Ac 9:1). There is little doubt about the topic and person that preoccupied Paul. It is not a surprise then that this person should be part of his ecstatic trance experience. From a neurological perspective, Paul's intense focus on persecuting followers of Jesus could have induced an altered state of consciousness "from the top down."

This focus would also help explain how Paul came to recognize the one who was appearing to him (Goldman 1999). For one, Paul the Pharisee would be familiar with "the world to come" as it contrasts with "this world." Paul would know that holy men abide in the world to come with God and other spirits (Pilch 1998a). It is important to acknowledge that people like Paul (e g, fellow Israelites) who believe in this alternate reality (the world to come) also know that beings from there can readily visit and intervene in the life and consciousness of human beings in culturally "normal" reality (e g, Lk 2:26-38). Indeed, beings from alternate reality are most likely to visit those who are familiar with them rather than those completely unfamiliar with them. In other words, it would not seem plausible for Paul to see or experience Confucius. So when Paul learns the identity of the one appearing to him in trance, many things fall instantly into place. This Jesus (of Nazareth) who died a shameful death and now comes from alternate reality (in Israelite tradition, the world to come) to speak with one who has hated him, this Jesus must most certainly be pleasing to God, acceptable to God or he wouldn't be with God in the world to come. Paul's choice is to halt the trance, perhaps deny it, or accept its message and respond accordingly. It is clear from Paul's letters that he recognized that God was instrumental in his having these ecstatic trance experiences. "But when he who had set me apart before I was born ... was pleased to reveal his Son to [Greek: in] me ...” (Gl 1:15-16). God took the initiative. 
In stage two of an ecstatic trance experience, the visionary selects objects of personal, religious, emotional, or other significance and seeks to impose them on his or her trance experience in order to begin to make sense of that experience. Sometimes the visionary's emotional state influences the interpretation. Paul, "breathing threats" (Ac 9:1) and "in raging fury against them [believers in Jesus]" (Ac 26:11) was certainly obsessed with Jesus and his followers. Moreover, his behavior was rooted in his Torahrooted conviction that Jesus and his followers, fellow members of the House of Israel, were not at all faithful to the God of the Covenant. The dialogue between Paul and the risen Jesus quite clearly emerges from Paul's emotional state and the circumstances of his commission to hunt down and imprison those who believe in Jesus.

Anthropologists observe that the content of trance experiences is vacuous and that they come without a sound-track (Pilch 1993:240). It is the visionary who supplies the sound track. Paul clearly hears someone speaking to him, and Paul answers. In the first account, those with him heard the voice but saw no one (Ac 9:7). The "voice" could have been a sound culturally interpreted as communication coming from the sky, from alternate reality (for an example, see John 12:28-30). In the second account, they see the light but do not hear the voice (Ac 22:9). Paul's companions knew that he was in trance (saw the light or heard the voice), but they themselves were not experiencing trance as for instance, Peter, James, and John were at the time of Jesus' transfiguration (Mk 9:2-8 and parallels; see Pilch 1994).

The dialogue in all three accounts appears with very little variation. Lohfink $(1965,1966)$ has analyzed and identified it as a "dialogue with apparition" literary form. It has a tri-partite structure:

A1 Introductory formula A2 double vocative A3 question of Christ

B1 Introductory formula B2 question of Paul

C1 Introductory formula C2 Self presentation of Christ

C3 Mission ....saying to him "Saul, Saul!

Why do you persecute me?"

But he answered/I said "Who are you Lord?"

And he said...

Ac 9:5: 22:8; 26:15

"I am Jesus, the one whom you are persecuting...."

"But rise..."
Ac 9:4; 22:7; 26:14

Ac 9:5; 22:8; 26:15
(Ac 9:15; 22:14); 26:16 
Felicitas Goodman has identified four elements in the cultural patterning of a trance experience: (1) the one experiencing the vision is initially frightened and (2) does not recognize the figure. (3) The figure in the vision offers calming assurance (e g, "fear not") and (4) identifies self (e g, "It is I..."; see Pilch 1993). In the accounts of Paul's experience, there is no indication of fright, thus no need for a statement of calming assurance from the one appearing. The cultural patterning identified by Goodman is inclusive, but all elements do not have to occur in each experience. It is not surprising, therefore, that Lohfink (1966) identifies a "shorter version" of this literary form in which the self-presentation is lacking. Thus, God communicates with Ananias, and Ananias recognizes God immediately (Ac 9:10-11). Cornelius sees an angel of God coming to him and is in terror. Since Cornelius recognized his visitor from alternate reality, there was no need of self-identification (Ac 10:33-5; for other examples see Gn 22:1-2 and $1 \mathrm{Sm} \mathrm{3:4-15).}$

Lohfink's identification of this literary form and its variations surfaces a question commonly asked by scholars. Is this literary form nothing more than a literary device commonly used in the literature to talk about an encounter with God, an angel or other such beings? The form appears in the Septuagint and is already stable and fixed by the first century $\mathrm{AD}$. Or does the literary form embellish a very simple experience? In personal e-mail communication, Prof Bruce Malina pointed out that all of these textsegments report a predictable, Mediterannean cultural behavioral pattern. Since trance experiences are quite common ("normal") in the Circum-Mediterranean world, the culture prescribes the appropriate behavior. Recall the observation of Lewis-Williams (1996:12) that all people have to cope with different states of consciousness in one way or another. Culture offers one way of coping by prescribing predictable behavioral patterns, and Goodman has identified four elements that may be found in the pattern. The writing pattern that Lohfink and other form-critics identify in literature are, in Malina's words, "culturally specific wording patterns that derive from the social system. Genre always derives from the social system since genres are not part of language or the linguistic system." Since the social system also specifies the behavioral pattern by which altered states are experienced and interpreted, it is quite plausible that visionaries did 
behave in a way very much like the literary pattern presents Paul (and others) as behaving.

Paul is experiencing the Risen Jesus who now abides in the realm of God. The light communicates this in Paul's ecstatic trance at stage one of the trance. At stage two, Paul's attempt to make sense of his experience takes place through the dialogue reported. Lohfink correctly cautions that the interpreter cannot consider the dialogues in these three reports as a factual, word-for-word report. He describes them rather as facts-withinterpretation, and claims that it is impossible to date and determine where the facts end and the interpretation begins.

This is certainly true in the contemporary interpretation of ecstatic trance experience, especially group trance experiences such as those sponsored by the Cuyamungue Institute (Dr Felicitas Goodman, 114 East Duncan St, Columbus, OH 43202; http://www.cuyamungue.org). After an ecstatic trance experience session, each visionary records what she or he saw and heard. Then each shares with the group. Group members often recognize that they have visited the same alternate reality but interpreted it differently. The interpretation of one can often clarify the experience and interpretation of another. In the process, it often seems that the "fact" is clarified (or re-created?) and definitely interpreted.

From the perspective of cognitive neuroscience, it is possible to gain an even clearer understanding of the reports about Paul's call given by Luke. Cognitive neuroscience tells us that there are two distinct neuroanatomical and neurophysiological mechanisms in the brain (d'Aquili and Newberg 1999:149-150) . The first, the causal operator, perceives and/or imposes causal sequences in the organization of reality. It strives to impose control and order over reality. In other words, this mechanism in the brain always constructs fact-with-interpretation. The second mechanism, the holistic operator, involves the potential for developing and experiencing altered states of consciousness. ASC experiences are not linear but rather holistic. The experiences provide glimpses into the spirit world (scientists sometimes call spirits "personalized power sources") which can be and sometimes are generated or at least perceived by the causal operator. One result of such ASC experiences is a reorganization of personality structure or a realignment of the individual toward his or her world. According to Acts 
9:15, Paul learns from Ananias what Ananias learned in a trance experience from the Risen Jesus, that Paul was to be an instrument to proclaim Jesus before Gentiles, kings, and Israelites. Paul changes from one who persecutes followers of Jesus to one who proclaims Jesus. Moreover, his realignment to his world is so dramatic, many did not believe him or trust him (see Ac 9:21-25). The report in Acts 22:14 is similar. Ananias explains that the purpose of Paul's ASC experience was to learn God's will, to see Jesus, and to be a witness on his behalf to all people. In the final report, Acts 26:16, Paul learns directly from Jesus that he is appointed by him to bear witness "to the things in which you have seen me and to those in which I will appear to you." He mission is to the Gentiles. Of particular interest in verse 14 is the notice that Paul will obtain further instruction from Jesus in other ecstatic trance experiences, which of course Acts bears out (see 16:6-10; 18:9-10; 22:17-21; 23:11). Lohfink (1966) thinks that these experiences serve to place Paul on par with the eye-witness companions of Jesus, the Apostles. Perhaps it is more correct to say that Paul is presented as a prophet, especially with the allusions in Acts 22:16-18 to Ezekiel's vision (Ez 2:1, "rise or stand up"), Jeremiah's call ("deliver you" Jr 1:8, 19; go and speak "to whom I send you" Jer 1:7). The vision, then, not only qualifies Paul as prophet but provides the information he needs in order to speak the will of God for the here and now like all prophets do for the house of Israel (see Ac 21:21). At the same time, Paul's on-going experiences of Jesus in ecstatic trance illustrates what the biblical tradition knows very well: ASC experiences are the customary vehicle by which God and other beings in alternate reality communicate with human beings in culturally "normal" reality (see 1 Sm 3:1-21).

\section{CONCLUSION}

With regard to ecstatic trance experiences, such as the three reports of Paul's experience in Acts $9 ; 22 ; 26$, traditional exegesis tends to focus on the question of historicity and interpretation. Can one know what really happened? Did it really happen this way? What in the report is simply the result of reflection and/or the author's literary activity? Can a reader separate all of these elements? Cultural anthropology and cognitive neuroscience suggest that a different set of questions needs to be asked. Dr Felicitas Goodman remembers two key ideas she heard as a graduate student in stimulating 
lectures from Dr Erika Bourguignon at Ohio State University. One, altered states of consciousness are normal; two, they are institutionalized in many societies as part of religious observances. Thus instead of attempting to determine the facts of the biblical report, or to separate fact from interpretation in the report, the exegete ought to attempt as in this paper - to understand how this report would be received and understood by the original readers or listeners.

It is not only plausible but highly probable that Paul like many others in the Bible had ecstatic trance experiences. Acts of the Apostles reports more than twenty such experiences. The research, publications, and ongoing experiences of the religious anthropologist, Dr Felicitas Goodman and the Cuyamungue Institute, provide ample information on how to induce and interpret ecstatic trance experiences (see Gore 1995). New insights from cognitive neurosciences especially as reported by d'Aquili and Newberg explain why ecstatic trance is a pan-human experience. Moreover, cognitive neuroscience helps to understand that some of the elements reported in the Bible are not just literary devices (e g the association of God's glory with light) but the result of the normal functioning of the brain and nervous system. As these scientists indicate, God has hard-wired human beings for such experiences, and they are God's preferred mode of communication with human beings. No one of Paul's contemporaries denied his experiences. They all had to decide how to respond to the experiences and Paul's interpretation of them. Some accepted his change as authentic and honest, while others sought to have him put to death.

In conclusion, we offer a final epistemological observation drawn from comparing baseline consciousness with the experience of absolute unitary being in deep trance presented d'Aquili and Newberg (1999:202):

If we grant ontological priority to external reality, and if we grant that the laws of science and, hence, neurophysiology and neuropsychology as sciences reflect a reasonably significant isomorphism with external reality of absolute unitary being among those who have experienced it, and finally, if we consider the intense functional certainty that we all have of the reality of our everyday world made up of multiple discrete interacting beings, then we must 
conceive the brain as a machine that operates upon whatever it is that fundamental reality may be and produces at the very least two basic versions, both accompanied by profound subjective certainty of their objective reality. Thus, it seems that both God and our everyday world can be perceived by the brain and generated by the brain. At this level of analysis both statements are probably equally true. Whatever is anterior to the experience of God and the multiple contingent reality of everyday life is in principle unknowable, since that which is in any way known must be a transformation wrought by the brain.

\section{Works Consulted:}

Bourguignon, E 1979. Altered states of consciousness, in Bourguignon, E (ed), Psychological anthropology: An introduction to human nature and cultural dfferences, 233-269. New York: Holt, Rinehart and Winston.

Bourguignon, E 1976. Possession and trance in cross-cultural studies of mental health, in Lebra, W P (ed), Culture-bound syndromes, ethnopsychiatry, and alternate therapies, 47-55. Vol IV of mental health research in Asia and the Pacific. An East-West Center Book. Honolulu: The University Press of Hawaii.

Clottes, J \& Lewis-Williams, D 1996. The shamans of prehistory: Trance and magic in the painted caves. Text by J Clottes tr from the French by S Hawkes. New York: Harry N Abrams, Inc.

Craffert, P F 1999. Jesus and the shamanic complex: First steps in utilizing a social type model and historical figure. Neotestamentica 33(2), 321-342.

d'Aquili, E G, Laughlin, Jr., C D, McManus, J et al 1979. The spectrum of ritual: A biogenetic structural analysis. New York: Columbia University Press.

d'Aquili, E G \& Newberg, A B 1993. Liminality, trance, and unitary states in ritual and meditation. Studia Liturgica 23, 2-34.

d'Aquili, E G \& Newberg, A B 1999. The mystical mind: Proving the biology of religious experience. Minneapolis: Fortress.

Dowson, T A 1992. Rock engravings of Southern Africa. Johannesburg: Witwatersrand University Press. 
Esler, P 1992. Glossolalia and the admission of gentiles into the Early Christian community. BTB 22, 136-142.

Goldman, M S 1999. Expectancy operation: Cognitive-neural models and architectures, in Kirsch 1999:41-63.

Goodman, F D 1972. Speaking in tongues: A Cross-cultural study of glossolalia. Chicago: University of Chicago Press.

Goodman, F D 1990. Where the spirits ride the wind: Trance journeys and other ecstatic experiences. Bloomington \& Indianapolis: Indiana University Press.

Goodman, F D, Henny, J H, \& Pressel, E 1974. Trance, healing, and hallucination: Three field studies in religious experience. New York: Wiley.

Gore, B 1995. Ecstatic body postures: An alternate reality workbook. Introduction by Dr Felicitas Goodman. Santa Fe: Bear \& Company Publishing.

Kirsch, I (ed) 1999. How expectancies shape experience. Washington, DC: American Psychological Association.

Krippner, S 1972. Altered states of consciousness, in White, J (ed), The highest state of consciousness, 1-5. New York: Doubleday.

Lohfink, G 1965. Eine alttestamentliche Darstellungensform für Gotteserscheinungen in den Damaskusberichten (Apg 9; 22; 26). Biblische Zeitschrift 9, 246-257.

Lohfink, G 1966. Paulus vor Damaskus. Stuttgart: Katholisches Bibelwerk. (Stuttgarter Bibelstudien 4.)

Malina, B J 2001. The New Testament world. Third revised and expanded edition. Louisville: Westminster John Knox Press.

Malina, B J 1999. Assessing the historicity of Jesus' walking on the sea: Insights from cross-cultural social psychology, in Evans, C A \& Chilton, B (eds), Authenticating the activities of Jesus, 351-371. Leiden: Brill. (New Testament Tools and Studies 28.3.)

Malina, B J \& Pilch, J J 2000. Social science commentary on Revelation. Minneapolis: Fortress.

Pease, R W Jr 1993. Merriam-Webster's medical desk dictionary. Springfield: MerriamWebster, Inc.

Pilch, J J 1993. Visions in revelation and alternate consciousness: A perspective from cultural anthropology. Listening: Journal of Religion and Culture 28, 231-244. 
Pilch, J J 1994. The Transfiguration of Jesus: An experience of alternate reality, in Esler, P F (ed), Modelling early christianity: Social scientific studies of the New Testament in its context, 47-64. London: Routledge.

Pilch, J J 1996. Altered states of consciousness: A "Kitbashed" Model. BTB 26, 133138.

Pilch, J J 1998a. Appearances of the risen Jesus in cultural context: Experiences of alternate reality. $B T B 28,52-60$

Pilch, J J 1998b. A window into the Biblical world: Walking on the sea. The Bible Today 36(2), 117-123.

Pilch, J J 2002. Altered states of consciousness events in the synoptics, in Malina, B J, Stegemann, W, \& Theissen, G (eds), The social setting of Jesus and the Gospels. Minneapolis: Fortress.. German translation: Begebenheiten des veränderten Bewusstseinszustand bei den Synoptikern, in Malina, B J, Stegemann, W, \& Theissen, G (eds), Jesus in Neuen Konteksten Stuttgart: Kohlhammer. (Forthcoming.)

Pilch, J J 2004. Acts of the apostles: How the early believers encountered God. Collegeville, MN: The Liturgical Press. (Forthcoming.)

Rakowska, J M 2000. Terapia Krótkoterminowa. Warszawa: Wydawnictwo Naukowe PWN.

Reichel-Dolmatoff, G 1978. Beyond the milky way: Hallucinatory imagery of the Tukano Indians. Los Angeles: UCLA Latin American Center.

Rossi, E L 1986. Altered states of consciousness in everyday Life: The Ultradian rhythms, in Wolman, B B \& Ullman, M (eds), Handbook of states of consciousness, 97-132. New York: Van Nostrand Reinhold Co.

Siegel, R K 1977. Hallucinations. Scientific American 237, 132-140.

Winkelman, M 1997. Altered states of consciousness and religious behavior, in Glazier, S D (ed), Anthropology of religion, 393-428. London and Westport: Praeger.

Winkelman, M 1982. ${ }^{2}$ Magic: A theoretical reassessment. Current Anthropology 23, 3766.

${ }^{2}$ See especially the response by Felicitas Goodman, p 47. 